\title{
Psychological states of career wellbeing and affective commitment as predictors of dual career agility types
}

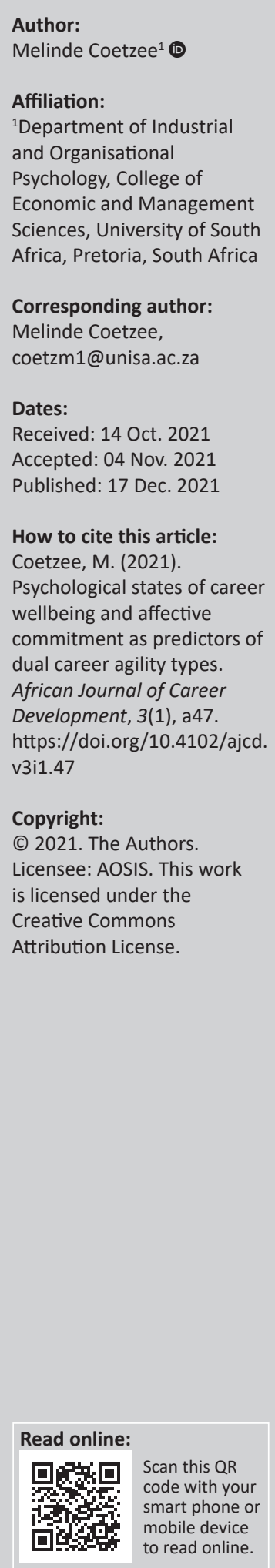

Background: There is limited empirical research on the construct of career agility and the relevance of dual career agility types in the technological-driven workplace.

Objective: This study aimed to adopt a person-centred approach in assessing the link between dual career agility types and individuals' psychological states of career wellbeing and affective commitment.

Method: The cross-sectional survey involved a sample of $(n=298)$ managers $(71 \%)$ and staff $(29 \%)$ employed in the human resource and financial services industry. The sample comprised of men $(54 \%)$, women $(46 \%)$, including black people $(62 \%)$ and white people $(38 \%)$ with a mean age of 38.58 years.

Results: The results provided deeper insight into the psychological states of career wellbeing and affective commitment that accounted for the personally-autonomous motives that are embedded in the three dual career agility types.

Conclusion: The findings brought a more holistic understanding of the nature of person-centred career agility motives and the psychological states that elucidate these motives. The findings bring new insights that might foster optimal career development and employees' adaptation to the post-COVID pandemic digital era workplace.

Keywords: career agility; dual career agility types; career wellbeing; affective commitment; autonomous motives.

\section{Introduction}

People's career agility matters in today's more turbulent world of work. Career agility denotes individuals' appropriate and speedy responsiveness to technological-driven change (Coetzee, Ferreira, \& Potgieter, 2021a; Giulioni, 2021; Konstant, 2020; Paulino, 2020). Career agility matters because individuals strive for career satisfaction and success that are engendered when they sustain their employability and are able to autonomously craft meaningful careers that support a sustainable livelihood (Coetzee \& Schreuder, 2021; Konstant, 2020). Despite the disruption that the COVID-19 pandemic brought to people's career trajectories, the pandemic also gave rise to new opportunities for career exploration, change and development because of changing work arrangements and skills upgrades made possible by new technological developments (Akkermans, Richardson, \& Kraimer, 2020; Alisic \& Wiese, 2020; Nilforooshan, 2020).

Career agility enables individuals to embrace and capitalise on the new work and career opportunities offered by the digital era employment market (Coetzee et al., 2021a; Giulioni, 2021; Konstant, 2020). However, along with changes in the work environment, the relationships between individuals and organisations as spaces offering work and career development opportunities are becoming more complex (McElroy \& Weng, 2016). Whilst individuals are becoming more career agile in the autonomous pursuit of career goals for continued career growth and success, organisations also recognise the need for providing career development support that will facilitate commitment and career wellbeing for optimal employee and sustainable business performance in a technological competitive global market (Coetzee \& Bester, 2021; McElroy \& Weng, 2016; Sungu, Weng, \& Kitule, 2019).

Relationship motivation theory, a mini-theory of self-determination theory (Deci \& Ryan, 2014; Gore, Bowman, Grosse, \& Justice, 2016) explains the tension between individuals' personallyautonomous reasons (or motives) for career agility and their relationally autonomous reasons 
for remaining committed to an organisation's goals. Individuals' career agility is promoted by the social context as a mechanism for the satisfaction of their basic psychological need for autonomy (Gore et al., 2016). Autonomy is fundamental to individuals' sense of self and wellbeing because it denotes the degree to which individuals perceive themselves as agents of their own actions and goal attainment successes (Deci \& Ryan, 1991). Organisations are important relational career development spaces that help individuals feel connected, competent and engaged in self-endorsing autonomous activities (Coetzee \& Engelbrecht, 2020). Coetzee (2021) found that certain states of career wellbeing predict facets of career agility. However, it is unclear to which degree the psychological states of career wellbeing and affective commitment jointly (as relationally-autonomous motives for career development) predict dual career agility types (i.e. unique personally-autonomous motives for career development).

The present study fills this gap in research. The aim of the study was to firstly adopt a person-centred approach by using Coetzee's (2021) theoretical combinations of three dual career agility types as outcome variables denoting individuals' personally-autonomous motives for career development. However, empirical research on the three dual career agility types has not yet been conducted. Secondly, the study goes one step further by exploring the psychological states of career wellbeing and affective commitment as joint relationally-autonomous motivational antecedents of the dual career agility types (i.e. personally-autonomous motivational outcomes of career development) on a different sample of employees. Taking a person-centred approach to psychological constructs has been advocated by scholars because it allows for 'a more holistic understanding of how combinations' of psychological variables relate to other variables of a psychological nature (Meyer, Morin, Rousseau, Boudrias, \& Brunelle, 2021, p. 2). This approach enriches career development research and gives a better understanding of the psychological motives that drive career agile states and behaviour. The anticipated new knowledge is deemed essential for enhancing organisational career development support practices in the technological-driven world of work.

\section{Dual career agility types}

Career agility is a contemporary construct that denotes individuals' career adaptivity readiness or willingness to adapt to and proactively respond to technological-driven changes for sustainable career growth, success and employability (Coetzee et al., 2021a; Giulioni, 2021; Konstant, 2020; Paulino, 2020). Coetzee et al. (2021a) describe three facets of career agility, namely technological adaptivity, agile learning and career navigation. Technological adaptivity denotes an optimism towards technological advancement and change, including an eagerness to update one's skills and knowledge to adapt to, capitalise on, and search out the new job and career opportunities made possible by technological advancement. Agile learning refers to the intrinsic motivational drive to set and manage the achievement of career goals, including goals for continuous upskilling and development opportunities. Career navigation describes personal confidence in one's ability to adapt to change, and to navigate and search out new job and career opportunities in a changing work and career environment (Coetzee et al., 2021a, p. 356).

Based on the arguments of Menatta, Consiglio, Borgogni and Moschera (2021) and Meyer et al. (2021), the notion of dual career agility types is based on the theoretical assumption that individuals simultaneously experience different forms of the three career agility facet motives to varying degrees. Coetzee (2021) argued that the three career agility facets can be combined into three meaningful combinations that denote certain shared motivational commonalities. These shared motivational commonalities describe unique specificities associated with psychological states of career adaptivity readiness.

Coetzee (2021) differentiates between the dual career agility types of the future-fit career adapter (combination of technological adaptivity and agile learning motives), the agentic adapter (a combination of technological adaptivity and career navigation motives), and the open-minded career adapter (a combination of agile learning and career navigation motives).

Future-fit career adapters exhibit agency in career adaptivity. They actively respond to changing technology-driven career/ socioeconomic changes; search out new career/job opportunities; actively market their personal brand/portfolio of skills across digital networks; and energetically set and manage career goals for continuous learning and growth in the changing employment and socioeconomic market (Coetzee, 2021). Agentic career adapters are in a state of activating their career adaptivity; they actively respond and adapt to taking advantage of technological change for upskilling, and optimising personal creativity, growth and happiness; they are confident in navigating and looking out for technological-driven new job roles and career opportunities for growth and creative self-expression (Coetzee, 2021). Open-minded career adapters are in a state of career adaptivity ideation; they are energetic and positive about searching for new and better growth opportunities; they also feel confident in their ability to navigate and adapt to change and uncertainty in the career environment (Coetzee, 2021).

Drawing from relationship motivation theory (Deci \& Ryan, 2014; Gore et al., 2016), it is argued that the dual career agility types represent personally-autonomous motives. Such motives reflect core self-endorsed traits, goals and life narratives that facilitate the self-regulated (autonomous) long-term and satisfying attainment of goals which are personally important to the individual. Personallyautonomous motives are associated with positive outcomes such as creative learning and engagement, greater energy 
and vitality, higher wellbeing and rewarding socialisation and relationships (Weinstein, Przybylski, \& Ryan, 2012). Personally-autonomous individuals are open to and interested in self-exploration and able to utilise awareness of their needs, values, interests, and feelings to act in a selfregulated, congruent fashion (Weinstein et al., 2012).

In the career agility context, personally-autonomous motives promote reasons for exhibiting career adaptivity (i.e. a readiness to adapt to the changing work and career environments). Research further shows that personallyautonomous motives produce better outcomes when integrated with relationally-autonomous motives (Gore et al., 2016). According to the relationship motivation theory (Deci \& Ryan, 2014; Gore et al., 2016), relationally-autonomous motives provide reasons for goals based on the needs, desires and commitments within a social relational context. In the career development context, relationally-autonomous motivational states provide reasons for why individuals join and stay committed to an organisation. Scholars agree that organisations provide an important supportive and instrumental context for career goal attainment, career growth and development, and career satisfaction. Organisational career development supportive conditions have also been associated with wellbeing and commitment (Coetzee \& Bester, 2021; Dahling \& Lairicella, 2017; Sungu et al., 2019). In the present study, the constructs of career wellbeing and affective commitment are treated as relationally-autonomous motivational states that support and enable the personally-autonomous motives embedded in individuals' career agility type.

\section{Psychological states of career wellbeing and affective commitment}

Career wellbeing alludes to an ongoing state of positive experiences of, and feelings about the career in the careersituated context (Coetzee, 2021; Coetzee, Ferreira, \& Potgieter, 2021b; Kidd, 2008). Career wellbeing often reflects affective judgments about the state of relationship between the employee and the organisation. Evaluations of the state of the relationship include emotional judgments about the meaningfulness of the organisational career, the nature of the career, the resources and opportunities for career development support and growth, and the availability of personal networks for career development support (Coetzee, 2021; Kidd, 2008). Research by Coetzee (2021) shows that positive evaluations of the state of career networking and social support in the organisation, and the meaningfulness of the organisational career explain the motives of technological adaptivity. Positive feelings about the meaningfulness of the organisational career and the resources and opportunities for career growth and development are associated with agile learning motives. Positive feelings about the state of the career networking and social support in the organisation also explain career navigation motives (Coetzee, 2021).
Affective commitment elucidates a psychological motivational state of being emotionally attached to an organisation (Meyer et al., 2021). The emotional bond with the organisation denotes relationally-autonomous motives whereby employees generally strongly identify with the organisation, feel that the organisation has personally meaning to them, and that they would be content to spend the rest of their career in the organisation (Meyer \& Allen, 1997). Previous research showed that the relationallyautonomous motivational state that underpins affective commitment positively explains individuals' general wellbeing and satisfaction (Meyer \& Maltin, 2010; Meyer et al., 2021).

The question remains whether there are significant associations between the psychological relationallyautonomous motivational states of career wellbeing and affective commitment, and the personally-autonomous motives represented by the three dual career agility types described by Coetzee (2021). The next section outlines the research method employed to answer this research question.

\section{Method}

\section{Participants}

A convenience sample of $(n=298)$ managers $(71 \%)$ and staff (29\%) level employees in the South African (70\%), Zimbabwean/ Nigerian (15\%) and elsewhere in Europe's (15\%) financial and human resource services industry participated in the crosssectional survey. The mean age of the sample was 38.58 years (s.d. $=9.34)$. The sample comprised of men $(54 \%)$ and women (46\%), including 62\% black people (African: $42 \%$; Coloured/ mixed race: $6 \%$; Indian: $14 \%$ ) and $38 \%$ white people.

\section{Measuring instruments}

Dual career agility types. The career agility scale (CAS) (Coetzee et al., 2021a, p. 356) measures three facets of career agility (technological adaptivity, agile learning and career navigation) on a 7-point Likert-type scale (1: strongly disagree; 7: strongly agree). Coetzee et al (2021a) reported construct validity and internal consistency reliability of the CAS. The present research used participants' scores on combinations of the three facets of career agility as described by Coetzee (2021, p. 38). Each of these combinations represents a specific psychological state of career adaptive readiness (Coetzee, 2021): (1) future-fit career adapter (a combination of scores on agile learning and technological adaptivity); (2) agentic career adapter (a combination of scores on technological adaptivity and career navigation); and (3) open-minded career adapter (a combination of scores on agile learning and career navigation). Examples of items represented by each of the three psychological states include the following: future-fit career adapter (e.g. 'I continually search for new opportunities to learn new skills that will improve my career and job success' /'I feel being responsive to change is important for my career success'); agentic career adapter (e.g. 'I feel that evolving job roles as a result of new technologies optimise my creativity, growth and happiness' /'I take advantage of changes in my job and career environment'); and open-minded career adapter (e.g. 'I feel alive and full of energy'/'I am able to navigate and adapt to change and 
uncertainty in my job and career environment'). The results section of this article reported good internal consistency reliability and discriminant validity for these combinations of the career agility facets.

Career wellbeing. The CWS(Coetzee et al., 2021b, p. 5) measures three states of career wellbeing on a seven-point Likert-type scale $(1=$ strongly disagree; 7 = strongly agree): positive affective career state (6 items: e.g. 'I feel satisfied with my career progress and growth'); state of career meaningfulness (4 items: e.g. 'My job and career contribute to a bigger picture'), and career networking/social support state (4 items: e.g. 'I have a network of people that support me in my career'). Coetzee et al. (2021b) reported high internal consistency reliability and construct validity of the CWS.

Affective commitment: The affective commitment subscale of the Organisational Commitment Scale (OCS: Meyer \& Allen, 1997) measures the construct on a 7-point Likert-type scale $(1=$ strongly disagree to $7=$ strongly agree). Four items of the affective commitment subscale were included in the measurement model (e.g. 'I would be very happy to spend the rest of my career in this organisation'). The OCS has good reported internal consistency reliability and construct validity (Meyer \& Allen, 1991)

\section{Procedure}

The participants were invited via the professional LinkedIn online platform to complete the research questionnaire. A URL link to the research questionnaire was included in the invitation.

\section{Considerations of ethics}

The University of South Africa (Ethics certificate reference: ERC Ref\#: 2020_CEMS/IOP_014) provided ethical clearance and permission to conduct the research. The research questionnaire included a cover page that ensured the voluntary participation, privacy, anonymity and confidentiality of all the participants. Informed consent for the group-based data to be used solely for research purposes was obtained from all participants.

\section{Data analysis}

Descriptive statistics, bivariate correlations, confirmatory factor analysis (CFA) and multiple regressions were performed by using SAS/STAT® software version 9.4M5○ (2017).

\section{Results \\ Descriptive results}

Table 1 shows that the mean scores ranged from 5.07 (agree slightly: career networking/social support state) to 6.04 (generally agree: future-fit career adapter). The internal consistency reliability coefficients of the scale variables were acceptable to high $(\geq 0.69$ to $\geq 0.91)$. The bi-variate correlations between the three psychological states of career adaptive readiness (i.e. career agility facet combinations) and the career wellbeing constructs were positive and ranged between $r \geq 0.29$ and $r \leq 0.51$ ( $p=0.000$; small to large practical effect). The career wellbeing constructs had positive correlations with affective commitment ( $r \geq 0.47$ to $r \leq 0.52$; $p=0.000$; moderate practical effect). Affective commitment had small practical effect positive correlations with the future-fit career adapter $(r=0.14 ; p=0.01)$, the agentic career adapter $(r=0.19 ; p=0.01)$, and the open-minded career adapter $(r=0.29 ; p=0.01)$ career agility facet combination constructs.

\section{Discriminant validity of the measurement model}

Table 2 shows that the career agility facet combinations CFA model had an acceptable fit with the data suggesting evidence of discriminant validity amongst the three psychological states of career adaptivity readiness (i.e. career agility facet combinations): Chi-square $/ \mathrm{df}=3.66$ ( $p=$ 0.0001 ); $\mathrm{RMSEA}=0.09$ and $\mathrm{SRMR}=0.06 ; \mathrm{CFI}=0.87$ (close to 0.90). To test discriminant validity of the measurement model, a one factor CFA was first tested to assess whether the three career agility facet combinations, three career wellbeing constructs and the affective commitment construct loaded onto an overall factor. Table 2 shows that the one-factor CFA did not have good model fit. A multifactor CFA was then tested with the best fit items of the career agility facet combinations, the items of the three career wellbeing constructs, and the items of the affective commitment construct loading each onto their respective constructs. Table 2 shows that the overall measurement model had a good fit with the data and that discriminant validity was thus evident: Chi-square $/ \mathrm{df}=2.39(p=0.000)$; RMSEA $=0.07 ;$ SRMR $=0.07 ; \mathrm{CFI}=0.90$.

The final CFA overall measurement model for the career agility facet combinations showed a specific combination of

\begin{tabular}{|c|c|c|c|c|c|c|c|c|c|c|c|c|}
\hline Number & Variables & $\begin{array}{l}\text { Cronbach } \\
\text { alpha: } \alpha\end{array}$ & CR & Mean & SD & 1 & 2 & 3 & 4 & 5 & 6 & 7 \\
\hline 1 & Future-fit career adapter & 0.83 & 0.83 & 6.04 & 0.88 & - & - & - & - & - & - & - \\
\hline 3 & Open-minded career adapter & 0.82 & 0.83 & 5.78 & 0.96 & $0.64 * * *$ & $0.66 * * *$ & - & - & - & - & - \\
\hline 4 & Positive affective career state & 0.91 & 0.91 & 5.11 & 1.24 & $0.42 * * *$ & $0.38 * * *$ & $0.52 * * *$ & - & - & - & - \\
\hline 5 & State of career meaningfulness & 0.86 & 0.87 & 5.84 & 1.07 & $0.38 * * *$ & $0.29 * * *$ & $0.51 * * *$ & $0.70 * * *$ & - & - & - \\
\hline 7 & Affective commitment & 0.86 & 0.86 & 5.34 & 1.02 & $0.14 * *$ & $0.19 * *$ & $0.29 * *$ & $0.52 * * *$ & $0.48 * * *$ & $0.47 * * *$ & - \\
\hline
\end{tabular}

$\mathrm{CR}$, composite reliability; SD, standard deviation.

**, $p \leq 0.01 ; * * *, p \leq 0.000$. 
TABLE 2: Discriminant validity of the measurement model $(n=298)$.

\begin{tabular}{|c|c|c|c|c|c|c|}
\hline Model & Chi-square/df & $p$ & RMSEA & SRMR & CFI & AIC \\
\hline Career agility facet combinations & 3.66 & 0.0001 & 0.09 & 0.06 & 0.87 & 531.56 \\
\hline $\begin{array}{l}\text { One-factor CFA: Career agility facet combinations, career wellbeing } \\
\text { subfactors, affective commitment }\end{array}$ & 5.75 & 0.000 & 0.13 & 0.13 & 0.50 & 4412.90 \\
\hline $\begin{array}{l}\text { Multi-factor CFA: Career agility facet combinations, career wellbeing } \\
\text { subfactors, affective commitment }\end{array}$ & 2.39 & 0.000 & 0.07 & 0.07 & 0.90 & 1016.8 \\
\hline
\end{tabular}

df, difference; RMSEA, Root Mean Square Error of Approximation; SRMR, Standardised Root Mean Square Residual; CFI, Comparative fit index; AIC, Akaike Information Criterion.

TABLE 3: Regression of career wellbeing and affective commitment upon the career agility facet combinations.

\begin{tabular}{|c|c|c|c|c|c|c|}
\hline Variable & Unstd $\beta$ & $\operatorname{Std} \beta$ & s.e. & $t$ & $F$ & $R^{2}$ \\
\hline \multicolumn{7}{|l|}{ Future-fit career adapter } \\
\hline Positive affective career state & 0.23 & 0.35 & 0.05 & $4.17 * * *$ & $24.18 * * *$ & 0.25 \\
\hline State of career meaningfulness & 0.11 & 0.15 & 0.06 & $1.98^{*}$ & - & - \\
\hline Career networking/social support state & 0.11 & 0.16 & 0.05 & $2.34 * *$ & - & - \\
\hline Affective commitment & -0.12 & -0.19 & 0.04 & $-3.06 * *$ & - & - \\
\hline \multicolumn{7}{|l|}{ Agentic career adapter } \\
\hline Positive affective career state & 0.20 & 0.31 & 0.06 & $3.70 * * *$ & $18.24 * * *$ & 0.20 \\
\hline State of career meaningfulness & 0.08 & 0.11 & 0.06 & 1.50 & - & - \\
\hline Career networking/social support state & 0.11 & 0.17 & 0.05 & $2.32 *$ & - & - \\
\hline Affective commitment & -0.13 & -0.21 & 0.04 & $-3.33 * * *$ & - & - \\
\hline \multicolumn{7}{|l|}{ Open-minded career adapter } \\
\hline Positive affective career state & 0.22 & 0.33 & 0.06 & $4.05 * * *$ & $27.06 * * *$ & 0.27 \\
\hline State of career meaningfulness & 0.17 & 0.22 & 0.06 & $3.00 * *$ & - & - \\
\hline Career networking/social support state & 0.09 & 0.13 & 0.05 & $1.96 *$ & - & - \\
\hline
\end{tabular}

Unstd, unstandardiseed; Std, standardized; s.e., standard error.

$*, p \leq 0.05 ; * *, p \leq 0.01 ; * *, p \leq 0.001$.

the facets' items that specify the unique personally autonomous motives of the relevant dual career agility type:

- Future-fit career adapter: Included the facet combination construct of technological adaptivity (actively respond to change for career success) and three items of the agile learning construct (actively sets and manages career goals, sees oneself as continually learning, growing, improving, and continually searches for opportunities to learn new skills that will improve career and job success).

- Agentic career adapter: Included two items of the technological adaptivity construct (feels that evolving job roles as a result of new technologies optimise one's creativity, growth and happiness, and that the acceleration of technology brings new, exciting job and career opportunities), and one item of the career navigation construct (is confident in taking advantage of changes in one's job and career environment).

- Open-minded career adapter: Included one item of the agile learning construct (feels alive and full of energy to learn and grow for career success), and three items of the career navigation construct (is comfortable with change, and is confident in one's ability to easily adapt to, and navigate changes and uncertainty in one's job and career environment, and one's career situation).

\section{Multiple regression analysis}

Table 3 shows that the three Analysis of Variance (ANOVA) models were significant $(p=0.001)$. The ANOVA of the future-fit career adapter explained $25 \%\left(R^{2}=0.25\right.$; moderate practical effect) of the variance in the construct. The ANOVA of the agentic career adapter explained $20 \%\left(R^{2}=0.20\right.$; moderate practical effect) of the variance in the construct. The ANOVA of the open-minded career adapter explained $27 \%\left(R^{2}=0.27\right.$; large practical effect $)$ of the variance in the construct. The tolerance values for all three ANOVA models ranged between 0.38 and 0.69 whilst the variance inflation factor (VIF) values ranged between 1.45 and 2.63. These values indicated that multicollinearity was not a major concern in the interpretation of the findings.

Across all three regression models, the positive affective career state (career wellbeing) contributed the most in explaining a significant positive variance in the three career agility facet combinations: future-fit career adapter $(\beta=$ $0.35 ; p \leq 0.001)$, agentic career adapter $(\beta=0.31 ; p \leq 0.001)$, and open-minded career adapter $(\beta=0.33 ; p \leq 0.001)$. Affective commitment showed a significant negative prediction of the three career agility facet combinations: future-fit career adapter $(\beta=-0.19 ; p \leq 0.01)$, agentic career adapter $(\beta=-0.21 ; p \leq 0.001)$, and open-minded career adapter $(\beta=-0.19 ; p \leq 0.01)$. State of career meaningfulness $(\beta=0.22 ; p \leq 0.01)$ had a stronger prediction effect on the open-ended career adapter mindset than affective commitment $(\beta=-0.19 ; p \leq 0.01)$. State of career meaningfulness was not a significant predictor of the agentic career adapter. Affective commitment had a stronger prediction effect on the future-fit career adapter $(\beta=-0.19$; $p \leq 0.01)$ and agentic career adapter $(\beta=-0.21 ; p \leq 0.001)$ than the career networking/social support state: future-fit adapter $(\beta=0.16 ; p \leq 0.01)$; agentic career adapter $(\beta=0.17$; $p \leq 0.05)$. 
TABLE 4: Dual career agility types and their psychological states of career wellbeing and affective commitment.

\begin{tabular}{|c|c|c|c|}
\hline \multirow[t]{2}{*}{ Dual career agility types } & Future-fit career adapter & Agentic career adapter & Open-minded career adapter \\
\hline & $\begin{array}{l}\text { Dual career agility type: } \\
\text { Technological adaptivity/ } \\
\text { Agile learning }\end{array}$ & $\begin{array}{l}\text { Dual career agility type: } \\
\text { Technological adaptivity/ } \\
\text { Career navigation }\end{array}$ & $\begin{array}{l}\text { Dual career agility type: } \\
\text { Agile learning/ } \\
\text { Career navigation }\end{array}$ \\
\hline $\begin{array}{l}\text { Strongest explanatory } \\
\text { predictors }\end{array}$ & $\begin{array}{l}\text { High positive affective career state } \\
\text { Low affective commitment }\end{array}$ & $\begin{array}{l}\text { High positive affective career state } \\
\text { Low affective commitment }\end{array}$ & $\begin{array}{l}\text { High positive affective career state } \\
\text { Positive state of career meaningfulness }\end{array}$ \\
\hline $\begin{array}{l}\text { Relationally-autonomous } \\
\text { motives (strongest } \\
\text { predictor) }\end{array}$ & $\begin{array}{l}\text { Has necessary support and resources in place to } \\
\text { achieve career goals; makes satisfactory career } \\
\text { progress; and career enables upskilling for new } \\
\text { employment opportunities. } \\
\text { Low personal identification with the organisation }\end{array}$ & $\begin{array}{l}\text { Has the necessary support and resources in place } \\
\text { to achieve career goals; makes satisfactory career } \\
\text { progress; and career enables upskilling for new } \\
\text { employment opportunities. } \\
\text { Low personal identification with the organisation }\end{array}$ & $\begin{array}{l}\text { Has the necessary support and resources in place } \\
\text { to achieve career goals; makes satisfactory career } \\
\text { progress; and career enables upskilling for new } \\
\text { employment opportunities; career is a personal } \\
\text { choice, is interesting, worthwhile and contributes } \\
\text { to a larger purpose }\end{array}$ \\
\hline $\begin{array}{l}\text { Supportive explanatory } \\
\text { predictors }\end{array}$ & $\begin{array}{l}\text { Positive career networking/social support state } \\
\text { Positive state of career meaningfulness }\end{array}$ & Positive state of career networking/social support & $\begin{array}{l}\text { Low affective commitment } \\
\text { Positive state of career networking/social support }\end{array}$ \\
\hline $\begin{array}{l}\text { Relationally-autonomous } \\
\text { motives (supportive } \\
\text { predictors) }\end{array}$ & $\begin{array}{l}\text { Engages with network of career support for } \\
\text { development feedback and career goal } \\
\text { achievement; career is a personal choice, is } \\
\text { interesting, worthwhile and contributes to a } \\
\text { larger purpose }\end{array}$ & $\begin{array}{l}\text { Engages with network of career support for } \\
\text { development feedback and career goal } \\
\text { achievement }\end{array}$ & $\begin{array}{l}\text { Low personal identification with the organisation; } \\
\text { engages with a network of career support for } \\
\text { development feedback and career goal } \\
\text { achievement }\end{array}$ \\
\hline
\end{tabular}

\section{Discussion}

The results provided deeper insight into the psychological states that accounted for the personally-autonomous motives that are embedded in the three dual career agility types. Table 4 summarises the core findings in answering the research question whether there are significant associations between the psychological relationallyautonomous motivational states of career wellbeing and affective commitment, and the personally-autonomous motives represented by the three dual career agility types described by Coetzee (2021).

Table 4 shows that a positive affective career state and low identification with the organisation explained the personallyautonomous motives that are exhibited by the three dual career agility types. The findings suggest that positive feelings about career development support and resources for achieving career goals, making career progress and having upskilling opportunities to find new employment easily (Coetzee et al., 2021b), are important relationally-motivational-states that translate into activated self-regulated, autonomous career agility motives.

It further appears from the findings that the career agility motives are strengthened when individuals feel less emotionally attached to the organisation, that is, they become more willing to explore new job and career opportunities that the external employment market offers as a result of technological advancement. This mindset seems especially true of the future-fit career adapter and the agentic career adapter and to a lesser extent the open-minded career adapter. The finding can be attributed to the notion that motives of autonomy relate to the centrality of the selfregulated career in the individual's life. Autonomous individuals experience themselves as the authors of their career behaviour, values, needs and interests, not the organisation (Weinstein et al., 2012). The organisation only provides the social context for opportunities for selfexpression, growth and upskilling (Coetzee \& Bester, 2021). Self-determination theory (Deci \& Ryan, 2014; Janssen, Van Vuuren, \& De Jong, 2013) explains in this regard that both contextual (career supportive work environment) and intrapersonal factors facilitate the internalisation of external requirements (i.e. technological-driven employment market) into autonomous motivations, which explains the positive association between states of career wellbeing and the dual career agility types.

A positive state of career networking/social support seems also an important enabler of the three sets of dual career agility motives. This finding is in agreement with research that shows positive associations between networking and career optimism. Networking is generally seen as an essential career self-management strategy that enhances people's access to supportive resources and career success (Janasz \& Forret, 2008; Volmer, Shulte, Handke, Rodenbücher, \& Tröger, 2021). Positive feelings about social support were also shown to improve adaptivity, self-efficacy and social adaptation capabilities (Wang \& Fu, 2015).

A positive state of career meaningfulness was positively associated with the future-fit career adapter and openminded career adapter but not the agentic career adapter. The finding could be attributed to the relationallyautonomous motivational need for the career to be a personal choice, and experiencing the career as interesting, worthwhile and contributing to a larger purpose in a particular social context (Coetzee, 2021). Both the future-fit career adapter and open-minded career adapter are associated with motives of agile learning. Research by Coetzee (2021) also shows positive associations between a state of career meaningfulness and agile learning. A sense of the job and career being meaningful is also associated with positive career outcomes such as satisfaction with career development (Lysova, Allan, Dik, Duffy, \& Steger, 2019). 
Practically, career counsellors and human resource practitioners should recognise the importance of autonomy motives in self-regulated career development. The findings suggest that the satisfaction of employees' career wellbeing needs through supportive organisational career development practices will facilitate important selfregulated career agility motives that enhance employees' readiness to adapt to the rapidly changing work contexts. Individuals should learn that although the organisation provides an important space for career development, they need to discover the personal meaning of their careers beyond the organisation. Career development practices could include support in the form of career discussions on employees' feelings about the nature of their careers, their need for career growth and upskilling, including the resources they need to become more agile in their career. These career supportive practices foster positive affective career states that enhance individuals' career agility.

The results of the study suggest that career development support could focus on assessing the current state of career adaptivity readiness as exhibited by individuals' dominant dual career agility type. For example, individuals with a dominant open-minded career adapter attribute express their career adaptivity readiness as being open to change and being confident in their ability to navigate and adapt to changes in their career and job environment; that is, they are still in a state of ideation. Individuals with a dominant agentic career adapter attribute are in a state of activating their agency in self-regulated career management. They express their career adaptivity readiness as agentic (self-regulated) confidence in their ability to take advantage of changes in the job and career environment. They are optimistic that technological-driven evolving job roles bring new exciting job and career opportunities that will promote their creativity, growth and happiness.

Individuals with a dominant future-fit career adapter attribute are in an active state of agency. They express their career adaptivity readiness as self-regulated responsiveness to change for career success; they actively set and manage career goals and search out opportunities to learn new skills that will enhance their chances for career and job success. Their career agency is supported by a strong drive for continual learning, growing and improving themselves. Although all three states of technological adaptivity, agile learning and career navigation are important attributes of career agility that individuals need to cultivate in today's world of work, the assessment of dual career agility types provides deeper insight into the current state of readiness to be actively career agile. In this regard, the study findings provide deeper insight into the extent to which the relationally-autonomous motives of career wellbeing and affective commitment influence individuals' dominant state of career agility.

The study findings should be interpreted in the light of the limitations of the research design. The study was a crosssectional survey involving staff and managers in the human resources and financial industry. This may limit the generalisability of the study findings to other occupational contexts. Cause-effect associations could also not be established. Notwithstanding the limitations, the research provides a new direction for research on the modern-day construct of career agility. Future studies may adopt a longitudinal research design and consider further investigating the presence of dual career agility types in relation to other career constructs in different occupational contexts. Such studies may help to further illustrate the benefits of a person-centred approach in the career development context.

\section{Conclusion}

In sum, the findings allowed for a more holistic understanding of the nature of career agility motives in relation to the psychological states of career wellbeing and affective commitment. Career counsellors and human resource practitioners should recognise that people's career agility can vary in autonomous motives and consider carefully how they might foster optimal career development and employees' readiness for agency in adapting to the post-COVID pandemic digital era workplace.

\section{Acknowledgements Competing interests}

The author declares that she has no financial or personal relationships that may have inappropriately influenced her in writing this article.

\section{Author's contributions}

M.C. is the sole author of this article.

\section{Funding information}

This research received no specific grant from any funding agency in the public, commercial or not-for-profit sectors.

\section{Data availability}

Data availability only upon approval of the Unisa Research Ethics Committee upon formal request to the author.

\section{Disclaimer}

The views and opinions expressed in this article are those of the author and do not necessarily reflect the official policy or position of any affiliated agency of the author.

\section{References}

Akkermans, J., Richardson, J., \& Kraimer, A. [Editorial]. (2020). The Covid-19 crisis as a career shock: Implications for careers and vocational behaviour. Journal of Vocational Behavior, 119, 103434. https://doi.org/10.1016/j.jvb.2020.103434

Alisic, A., \& Wiese, B.S. (2020). Keeping an insecure career under control: The longitudinal interplay of career insecurity, self-management, and self-efficacy. Journal of Vocational Behavior, 120, 103431. https://doi.org/10.1016/j.jvb.2020.103431

Coetzee, M. (2021). Career wellbeing and career agility as coping attributes in the modern career space. In N Ferreira, I.L. Potgieter, \& M. Coetzee (Eds.), Agile coping in the digital era: Emerging issues for research and practice (pp. 35-51). Springer Nature. 
Coetzee, M., \& Bester, S.M. (2021). Exploring the reciprocal correspondence amongst workplace relationships, career goal instrumentality, career satisfaction, and workplace relationships, career goal instrumentality, career satisfaction, and
organisational commitment. South African Journal of Psychology, 51(1), 81-94. https://doi.org/10.1177/0081246320948366

Coetzee, M., \& Engelbrecht, L. (2020). How employability attributes mediate the link between knowledge workers' career adaptation concerns and their selfperceived employability. Psychological Reports, 123(4), 1005-1026. https:// perceived employability. Psychological
doi.org/10.1177/0033294119844981

Coetzee, M., Ferreira, N., \& Potgieter, I.L. (2021a). Assessing the construct validity of the Career Agility Scale for measuring adult workers' digital era adaptive readiness, Journal of Psychology in Africa, 31(4), 355-361. https://doi.org/10.108 0/14330237.2021.1952725

Coetzee, M., Ferreira, N., \& Potgieter, I.L. (2021b). Exploring the construct validity of the Career Wellbeing Scale for its application as a career development tool in the COVID-19 pandemic career space. African Journal of Career Development, 3(1), a39. https://doi.org/10.4102/ajcd.v3i1.39

Coetzee, M., \& Schreuder. A.M.G. (2021). Careers: An organisational perspective (6th ed.). Cape Town: Juta.

Dahling, J.J., \& Lauricella, T.K. (2017). Linking job design to subjective career success: A test of self-determination theory. Journal of Career Assessment, 25(3), 371-388. https://doi.org/10.1177/1069072716639689

Deci, E.L., \& Ryan, R.M. (1991). A motivational approach to self: Integration in personality. In R. Dienstbier (Ed.), Nebraska symposium on motivation (Vol. 38, pp. 237-288). Perspectives on Motivation. Lincoln, Nebraska, USA: NE University of Nebraska.

Deci, E.L., \& Ryan, R.M. (2014). Autonomy and need satisfaction in close relationships: Relationship motivation theory. In N. Weinstein (Ed.), Human motivation and interpersonal relationships: Theory, research and application (pp. 53-73) New York, NY: Springer.

Giulioni, J.W. (2021). Introducing the notion of career agility to the world of solopreneurship. Retrieved from https://www.juliewinklegiulioni.com/blog/ career-matters/introducing-the-notion-of-career-agility-to-the-world-ofsolopreneurship/

Gore, J.S., Bowman, K., Grosse, C., \& Justice, L. (2016). Let's be healthy together: Relational motivation for physical health is more effective for women. Motivation \& Emotion, 40, 36-55. https://doi.org/10.1007/s11031-015-9523-9

Kidd, J.M. (2008). Exploring the components of career well-being and the emotions associated with significant career experiences. Journal of Career Development 35(2), 166-186. https://doi.org/10.1177/0894845308325647

Konstant, M. (2020). Career agility for the future of your work. Retrieved from https:// networlding.com/career-agility-for-the-future-of-your-work/

Janasz, S.C., \& Forret, M.L. (2008). Learning the art of networkinmg: A critical; skill for enhancing social capital and career success. Journal of Management Education, 32(5), 629-650. https:doi.org/10.1177/1052562907307637
Janssen, S., Van Vuuren, M., \& De Jong, M.D.T. (2013). Identifying support functions in developmental relationships: A self-determination perspective. Journal of Vocational Behavior, 82, 20-29. http://doi.org/10.1016/j.jvb.2012.09.005

Lysova, E.I., Allan, B.A., Dik, B.J., Duffy, R.D., \& Steger, M.F. (2019). Fostering meaningful work in organizations: A multi-level review and integration, Journal of Vocational Behavior, 110(B), 374-389. https://doi.org/10.1016/j.jvb.2018.07.004

McElroy, J.C., \& Weng, Q. (2016). The connections between careers and organizations in the new career era: questions answered, questions raised. Journal of Career Development, 43(1), 3-10. https://doi.org/10.1177/08948445315604738

Menatta, P., Consiglio, C., Borgogni, L., \& Moschera, L. (2021). Dual commitment profiles and job satisfaction amongst temporary agency workers. Applied Psychology, 1, 1-24. https://doi.org/10.1111/apps.12333

Meyer, J.P., \& Allen, N.J. (1991). A three-component conceptualisation of organisational commitment. Human Resource Management Review, 1(1), 61-89. organisational commitment. Human Resource M
https://doi.org/10.1016/1053-4822(91)90011-Z

Meyer, J.P., \& Allen, N.J. (1997). Commitment in the workplace: Theory, research and application. Thousand Oaks, CA: Sage.

Meyer, J.P., \& Maltin, E.R. (2010). Employee commitment and well-being: A critical review, theoretical framework, and research agenda. Journal of Vocational Behavior, 77(2), 323-337. https://doi.org/10.1016/j.jvb.2010.04.007

Meyer, J.P., Morin, A.J.S., Rousseau, V., Boudrias, J., \& Brunelle, E. (2021). Profiles of global and target-specific work commitments: Why compatibility is better and how to achieve it. Journal of Vocational Behavior, 128, 103588. https://doi. org/10.1016/j.jvb.2021.103588

Nilforooshan, P. (2020). From adaptivity to adaptation: Examining the career construction model of adaptation. The Career Development Quarterly, 68, 98-111. https://doi.org/10.1002/cdq.12216

Paulino, K. (2020). Career agility - Four principles to create a meaningful development plan. Retrieved from https://www.linkedin.com/today/author/kellypaulino

SAS version 9.4M5@ (2017). SAS/STAT ${ }^{\circledR}$ software. Cary, NC: SAS Institute Inc

Sungu, L.J., Weng, Q., \& Kitule, J.A. (2019). When organizational support yield both performance and satisfaction. The role of performance ability in the lens of socia exchange theory. Personnel Review, 48(6), 1410-1428. https:/doi.org/10.1108/ PR-10-2018-0402

Volmer, J., Shulte, E., Handke, L., Rodenbücher, L., \& Tröger, L. (2021). Do all employees benefit from daily networking? The moderating effect of the affiliation motive. Journal of Career Development, 48(5), 555-568. https://doi. affiliation motive. Journal of Career
org/10.1177/0894845319873727

Wang, Z., \& Fu, Y. (2015). Social support, social comparison, and career adaptability: A moderated mediation model. Social Behavior and Personality, 43(4), 649-660. https://doi.org/10.2224/sbp.2015.43.4.649

Weinstein, N., Przybylski, \& Ryan, R.M. (2012). The index of autonomous functioning: Development of a scale of human autonomy. Journal of Research in Personality, 46, 397-413. https://doi.org/10.1016/j.jrp.2012.03.007 